\title{
Isolation and identification of phytate-degrading yeast from traditional fermented food
}

\author{
ADE ERMA SURYANI", AYU SEPTI ANGGRAENI, LUSTY ISTIQOMAH, EMA DAMAYANTI ${ }^{*}$, \\ MOHAMMAD FAIZ KARIMY \\ Research Center for Natural Product Technology, Indonesian Institute of Sciences. Jl. Raya Yogyakarta-Wonosari Km 31.5, Gading, Playen, \\ Gunungkidul 55861, Yogyakarta, Indonesia. Tel.: +62-274-392570, ^email: deyan02@gmail.com, ^v ema.damayanti@lipi.go.id
}

Manuscript received: 11 December 2020. Revision accepted: 17 January 2021.

\begin{abstract}
Suryani AE, Anggraeni AS, Istiqomah L, Damayanti E, Karimy MF. 2021. Isolation and identification of phytate-degrading yeast from traditional fermented food. Biodiversitas 22: 866-873. Application of phytase (myo-inositol hexakisphosphate phosphohydrolase) to catalyze the release of phosphate from phytates contained on grain-based feed has been used widely in poultry feed industry. In this study, yeast as phytase producer from traditional fermented food was isolated, screened and identified morphological, biochemical, and molecular characteristics. Production of extracellular phytase from yeast was quantified using spectrophotometer. The results showed that among 8 yeast isolates that had phytase activity, there were two isolates with the highest phytase activity and specific activity which were TKd3 isolate $(6.57 \mathrm{U} / \mathrm{mL}$ and $54.230 \mathrm{U} / \mathrm{mg})$ and $\mathrm{GF} 1(6.07 \mathrm{U} / \mathrm{mL}$ and $53.68 \mathrm{U} / \mathrm{mg})$. Morphological identification using Scanning Electron Microscope revealed that TKd3 cells isolated from soybean tempeh had an elongated oval cell structure, whereas the GF1 isolated from fresh gatot had a rounder cell structure. TKd3 isolate with accession number MW131530 had homology with Candida tropicalis ATCC 750 28S rRNA with 99.83\% similarity and GF1 isolate with accession number MW131531 had homology with Candida tropicalis ATCC 750 28S rRNA with 100\% similarity. It could be concluded that $C$. tropicalis yeast from traditional fermented food produced extracellular phytase for further use of phytase in poultry feed additive.
\end{abstract}

Keywords: Isolation, phytate-degrading yeast, traditional fermented food

\section{INTRODUCTION}

Phosphorus ( $\mathrm{P}$ ) is a component with important relevance in poultry feed. Grains, which represent an important component in poultry feed, have a high proportion in the poultry diet (Rodehutscord et al. 2016). However, $67 \%$ of total $\mathrm{P}$ in corn grain, legume seeds, oilseed plants, and cereal wastes contained in feed are bound to phytic acid (Steiner et al. 2007), thus most of the $\mathrm{P}$ in feed cannot be digested by monogastric animals such as poultry and pigs. For this reason, phytic acid acts as an antinutritional factor that inhibits the absorption of various minerals in poultry (Shanmugam et al. 2018). Phytic acid also causes environmental pollution by extra supplemented phosphorus in animal diets (Mittal et al. 2011). PhytatePhosphorus which is contained in feed and cannot be digested by poultry will be excreted through excreta.

In order to release phosphate from phytate-P binding required phytase to hydrolyze it. In poultry, phytase activity present in the brush border membrane of digestive tracts, but the activity was limited. Consequently, it cannot optimally hydrolyze phytate-P derived from feed (Abd ElHack et al. 2018). Phytase (myo-inositol hexakisphosphate phosphor hydrolases) is specifically hydrolyzing highly stable phytic acid (phytate) and releasing free myo-inositol phosphates and minerals. Phytase is widespread in nature. It is occurring in every plant system, dry seeds, and selected animal tissues (Savita et al. 2017). In various microorganisms such as bacteria, yeast, and fungi have been successfully investigated for extracellular phytase activity (Pandey et al. 2001). Phytase-producing microorganisms can be isolated from various sources, one of them is from traditional fermented food products (Basu et al. 2015) i.e bacterial groups such as Lactobacillus rhamnosus (RSJ13), L. brevis (JL1, JL3, JL7), $L$. fermentum (JL2, JL5, JL6, RS2, RS6) (Basu et al. 2015), $L$. plantarum (PKL-21), Pediococcus pentosaceus (PKL-17) and Enterococcus sp. (PKL-28) (Monica et al. 2017), fungal groups such as Aspergillus tubingensis (Qasim et al. 2016), A. niger, Rhizopus oryzae, Neurospora crassa and N. sitophila (Kanti and Sudiana 2016; 2018), while from the yeast group, derived of Saccharomyces cerevisiae, Pichia kudriavzevii (Noubariene et al. 2014), Issatchenkia orientalis, Hanseniaspora guilliermondii (Hellstorm et al. 2010), Candida. tropicalis (BOM210) and P. kluyveri (LKC17) (Ogunremi et al. 2015).

Fermentation process may assist in the detoxification of certain undesirable compounds such as toxin and antinutrients which may be present in grain-based raw foods, such as phytates, polyphenols, and tannins. Tempeh is one of Indonesian legume and grain fermented foods. Tempeh also considered an important part of diet due to its high nutritive value, digestibility, and reduced antinutrient compounds (Surono 2016). Some of traditional foods that common well in Indonesia made from fermentation processes (Sarwono 2010) such as gembus tempeh from processed tofu soy (Glycine max), soybean tempeh (Glycine max), lamtoro tempeh (Leucaenaleucocephala), 
and karabenguk tempeh (Mucunapruriens) (Damayanti et al. 2017). The microbes in tempeh are complex, involving mixed culture fermentation by molds, yeasts (Pangastuti et al. 2019), lactic acid bacteria (Efriwati et al. 2013), and various other bacteria. Yeast is one of microorganism that has great potential as an enzyme-producing microorganism, one of which is the phytase. The synthesis of phytases by yeasts is regulated by an external phosphate concentration and other factors such as: $\mathrm{pH}$, temperature, carbon sources, and occurrence of metal cations. The enzyme secretion can be intracellular, periplasmatic, directly to the culture medium or as bound to the cell wall (Greppi et al. 2015). However, the degradation activity of phytate from yeast in traditional fermented foods originating from Indonesia still not widely known.

Some research revealed that yeast group such as $S$. cerevisiae yeast L1.12 produced phytase specific activity of $42.9 \mathrm{U} / \mathrm{mg}, \quad P$. anomala was able to produce phytase activity of $7 \mathrm{mU} / \mathrm{mL}$ (Vohra and Satyanaraya, 2001), Arxula adeninivorans $\mathrm{J} 562$ was able to produce phytase specific activity of $22.2 \mathrm{U} / \mathrm{mg}, C$. bombi $\mathrm{J} 558$ with phytase specific activities of $19.7 \mathrm{U} / \mathrm{mg}, P$. anomala $\mathrm{J} 380$ with phytase specific activity of $18.9 \mathrm{U} / \mathrm{mg}$ (Olstrope et al. 2009), C. tropicalis was able to produce phytase specific activity of $1.95 \mathrm{IU} / \mathrm{mL}$ (Puppala et al. 2018) and $C$. parapsilosis $\mathrm{CB} 3$ was able to produce phytase specific activity of $41.3 \mathrm{U} / \mathrm{mL}$ (Ranjan and Sahay 2013). The use of phytase produced by yeast as feed additive becomes a solution for nutritional efficiency in poultry due to the high content of phytic acid as anti-nutrient in poultry feed. Phytase enzymes with high stability to environmental conditions are expected to work optimally in the digestive tract of poultry and can provide maximum results (Dersjant-Li et al. 2014). Based on the explanation above, it was known that a wide variety of yeast is involved in traditional fermented foods (Aidoo et al. 2005). Therefore the aim of this study was to determine the potential of phytate-degrading yeast isolated from Indonesian traditional grain-based fermented food.

\section{MATERIALS AND METHODS}

\section{Isolation of yeast from traditional fermented foods}

Yeast isolates were isolated from traditional fermented foods that originated from the Yogyakarta region and surrounding areas according to Torshizi et al. (2008). Traditional fermented food used consists of soybean tempeh (TKd), koro tempeh (TKr), gembus tempe (TGb), manding tempe (TMd), raw gatot (GF), and cooked gatot (GC). Sample of food was blend and suspended in $\mathrm{NaCl}$ $0.85 \%$, further serial dilution was conducted to get yeast isolates by inoculated in selective medium Chloramphenicol Yeast Glucose Agar (CYGA) and incubated at $30^{\circ} \mathrm{C}$ for 48 hours. The yeast colonies were detected by clearing zone appearance. Purification of isolates was conducted by repeating the scatter plate technique using the same selective media until pure colonies were obtained. A total of 1 yeast colony was suspended in $9 \mathrm{~mL}$ of $0.85 \% \mathrm{NaCl}$, then a serial dilution was carried out and grown on the CYG Agar medium, then incubated at $30{ }^{\circ} \mathrm{C}$ (anaerobic) for 48 hours. Three separate colonies were observed microscopically and microscopically to obtain a pure colony. Pure isolates were grown on CYG broth medium and incubated at $30^{\circ} \mathrm{C}$ for 48 hours, then homogenized and stored in $15 \%$ glycerol at -20 ${ }^{\circ} \mathrm{C}$ for stock culture.

\section{Qualitative screening of phytate-degrading yeast}

Qualitative screening of phytate-degrading activities by yeast isolates was carried out based on the modified cobalt chloride staining method by Bae et al. (1999). A total of 10 $\mu \mathrm{L}$ of yeast isolates were dripped on blank disc paper, then placed on the surface of the modified CYGA medium and incubated at $30^{\circ} \mathrm{C}$ for 48 hours. After incubation, disc paper was taken using tweezers, the colony on the surface of the CYGA medium was rinsed using distilled water and soaked in $2 \%(\mathrm{w} / \mathrm{v})$ cobalt chloride solution. After a 5 minutes incubation at room temperature, the cobalt chloride solution was replaced with a freshly prepared solution containing equal volumes of a $6.25 \%(\mathrm{w} / \mathrm{v})$ aqueous ammonium molybdate solution and $0.42 \%$ (w/v) ammonium vanadate solution. Then, the mixed solution (ammonium molybdate and ammonium metavanadate) removed and the diameter of the clear zone that formed was measured.

\section{Phytase production}

Phytase was produced according to Vohra and Satyanarayana (2001). Yeast was grown in PS broth [glucose, 10; sodium phytate, 3; $\left(\mathrm{NH}_{4}\right)_{2} \mathrm{SO}_{4}, \quad 3$; $\mathrm{MgSO}_{4} \cdot 7 \mathrm{H}_{2} \mathrm{O}, 0.5 ; \mathrm{KCl}, 0.5 ; \mathrm{CaCl}_{2}, 0.1$; trace elements (Lambrechts et al. 1992); (g/L); pH 5.6]. Sodium phytate and liquid medium were sterilized separately. Phytate was sterilized using syringe filter (Corning), while liquid medium was autoclaved at $121{ }^{\circ} \mathrm{C}$ for 15 minutes then both media were mixed before inoculation. Erlenmeyer flasks containing $50 \mathrm{~mL}$ PS broth were inoculated with $1 \%(\mathrm{v} / \mathrm{v})$ of yeast inoculum then incubated in an incubator shaker at $30{ }^{\circ} \mathrm{C}$ for 24 hours at $200 \mathrm{rpm}$. The cultures were harvested by centrifuging at $5000 \mathrm{rpm}$ for 30 minutes at $4{ }^{\circ} \mathrm{C}$. Cell free supernatants were collected as crude enzymes, stored at $4{ }^{\circ} \mathrm{C}$, and assayed for extracellular phytase.

\section{Phytase activity assay}

Measurement of phytase activity produced by yeast isolates was carried out based on the method of Vohra and Satyanarayana (2001). The crude enzyme was produced by liquid fermentation method in PS broth medium. Cell biomass and supernatant were separated by centrifugation method, and cell free supernatants were collected as a crude enzyme. The reaction mixture consisted of $1 \mathrm{~mL}$ of crude enzyme added with $0.5 \mathrm{~mL}$ of $0.1 \mathrm{M}$ acetate buffer $\mathrm{pH} 4.0$ and sodium phytate $1.5 \mu \mathrm{M}$ (in $0.1 \mathrm{M}$ acetate buffer $\mathrm{pH} 4$ ) then homogenized and incubated at $60{ }^{\circ} \mathrm{C}$ for 15 minutes. After incubation, the reaction mixture was added with $2 \mathrm{~mL}$ of $10 \%$ TCA, homogenized and added $1 \mathrm{~mL}$ of color reagent (ammonium molybdate 5.5\% in $1.5 \% \mathrm{H}_{2} \mathrm{SO}_{4}$ : $2.7 \%$ ferrous sulfate solution in $4: 1$ ratio) then incubated for 5 minutes at room temperature. The inorganic 
phosphate liberated was quantitatively determined in a spectrophotometer at $700 \mathrm{~nm}$. A standard curve was made by dissolving 0.0068 grams of $\mathrm{KH}_{2} \mathrm{PO}_{4}$ into $100 \mathrm{~mL}$ of 0.1 $\mathrm{M}$ acetate buffer $\mathrm{pH}$ 4. The standard initial concentration was $500 \mu \mathrm{M}$ and the calibration curve was made at a concentration of 50-500 $\mu \mathrm{M}$. One unit of phytase activity is defined as the amount of the enzyme that releases one $\mu \mathrm{g}$ inorganic phosphate per $\mathrm{ml}$ per min under the assay conditions (Qasim et al. 2016).

\section{Specific Phytase activity assay}

Specific phytase activity is the ability of phytase enzymes to degrade the substrate per $\mathrm{mg}$ of protein suspended in solution (Damayanti et al. 2017). Measurement of dissolved protein levels of phytase enzymes produced by yeast isolates was carried out based on Lowry et al (1951) method. The reaction mixture consisted of $0.5 \mathrm{~mL}$ of enzyme sample plus $0.5 \mathrm{~mL}$ of Lowry B reagent containing $1 \% \mathrm{CuSO}_{4} \cdot 10 \mathrm{H}_{2} \mathrm{O}$, $\mathrm{C}_{4} \mathrm{H}_{4} \mathrm{KNaO}_{6} \cdot 4 \mathrm{H}_{2} \mathrm{O} 2 \%, \mathrm{NaOH} 5 \mathrm{~N}$, and $\mathrm{Na}_{2} \mathrm{CO}_{3} 4 \%$ in $\mathrm{NaOH} 5 \mathrm{~N}$, then homogenized and incubated at room temperature for 15 minutes. After incubation, the reaction mixture was added with $1.5 \mathrm{~mL}$ of lowry A reagent (Folin's Ciaocalteu's phenol reagent $10 \%$ ) and then incubated at room temperature for 45 minutes. The absorbance of samples was measured with a spectrophotometer at a wavelength of $700 \mathrm{~nm}$. The standard is prepared by dissolving 0.015 grams of Bovine Serum Albumin (BSA) into $50 \mathrm{~mL}$ of distilled water. The standard protein concentration is $0.3 \mathrm{mg} / \mathrm{mL}$.

As previously mentioned, one unit of phytase activity is defined as the amount of the enzyme that releases one $\mu \mathrm{g}$ inorganic phosphate per $\mathrm{ml}$ per min under the assay conditions (Bonner 2007; Qasim et al. 2016).

$\begin{aligned} & \text { Specific enzyme } \\ & \text { activity }(\mathrm{U} / \mathrm{mg})\end{aligned} \quad=\frac{\text { Enzyme activity }(\mathrm{U} / \mathrm{mL})}{\text { Protein content in sample }(\mathrm{mg} / \mathrm{mL})}$

\section{Biochemical identification of selected yeast isolates}

Biochemical identification of selected yeast isolates with the highest phytase activity was conduct used API 20C Aux Kit. Yeast isolates were taken as much as one loop from stock culture, inoculated on solid CYGA medium, and incubated at $30{ }^{\circ} \mathrm{C}$ for 24 hours. Next, 4 single colony was taken from each yeast isolate and suspended into an ampoule containing $2 \mathrm{~mL}$ of $0.85 \%$ physiological $\mathrm{NaCl}$ solution, then homogenized. In the next step, the suspension was taken as much as $100 \mu \mathrm{L}$ and inoculated into an ampoule containing $7 \mathrm{~mL}$ of physiological solution of $0.85 \% \mathrm{NaCl}$. The suspension was then homogenized, and each of which was dropped $180 \mu \mathrm{L}$ into 20 holes on a plastic API 20C Aux kit containing 20 types of sugar. The API $20 \mathrm{C}$ Aux kit was incubated at $37^{\circ} \mathrm{C}$ for 72 hours. The change of color from clear to cloudy is stated as a positive test. Furthermore, isolate profiles were analyzed using API web software (BioMērieux).

\section{Morphology identification of selected isolate}

Morphology identification of selected yeast isolate was conducted with Scanning Electron Microscope (SEM). Directly sampling using loop needle from CYGA medium of selected yeast isolate and swab on carbon tape and then air-dried for a few minutes until dry out. To increase the yeast conductivity, samples were coated by gold $(\mathrm{Au})$ by ion sputter MC1000 (Hitachi Corp.) setting ten mA for 60 seconds and then observed using SEM setting $5 \mathrm{kV}$, SE detector, high vacuum mode, and magnification of $10.0 \mathrm{~K}$ (Karimy et al. 2020)

\section{Molecular identification of selected yeast isolate}

Isolation of yeast genomes, amplification, and sequencing of 28S rRNA gene sequences was carried out at Biotechnology Laboratory, Agency for Assessment and Application of Technology (BPPT), Serpong, Indonesia. The sequenced data were trimmed and assembled with the BioEdit program (Hall, 1999) and then converted in FASTA format. The DNA sequencing results in the following FASTA format at Basic Local Alignment Search Tool - Nucleotide (BLASTN) to locate the homology online at the DNA database center at National Center for Biotechnology Information (NCBI), available at https://blast.ncbi.nlm.nih.gov/Blast.cgi.

\section{Data analysis}

The length of cell from SEM was analyzed by ImageJ software (Schneider et al. 2012). The data of clear zone diameter, phytase activity, and specific phytase activity were evaluated using the analysis of variance (ANOVA) and the differences among mean treatments were analyzed using LSD (Gomez and Gomez 2007). Statistical analyses were performed with Costat software (Cohort 2008).

\section{RESULTS AND DISCUSSION}

\section{Isolation of yeast isolates from traditional fermented foods}

Isolation result showed that there were 17 isolates predicted as yeast-based on characterization of colony ( 8 isolates from soybean tempeh, 3 isolates from gembus tempeh, 1 isolate from manding tempeh, 2 isolates from koro tempeh, 2 isolates from fresh gatot, and 1 isolate from cooked gatot) (Table 1). According to Tabel 1, soybean tempeh has the largest number of yeast colonies. The microbes in tempeh are complex, involving mixed culture fermentation by molds, yeasts, lactic acid bacteria, and various other bacteria (Surono, 2016). Several types of yeast that have been reported in fermented foods and beverages, including mostly, are Candida glabrata, Candida inconspicua, Candida maris, Candida tropicalis, Candida diverca, Candida inconspicua, Candida pararugosa, Geotrichium penicillatum, Geotrichium candidum, Issatchenkia orientalis, Kluyveromyces lactis, Kluyveromyces marxianus, Saccharomyces cerevisiae, Saccharomyces lactis, Saccharomyces unisporus, Saccharomyces uvarum, Torulopsis kefir, Torula koumiss, etc. (Kabak and Dobson 2011). 
Some previous studies that use culture-dependent techniques showed that Rhizopus sp. plays the principal role in fermentation of soybean into tempeh, while the yeast and the bacteria are responsible for taste and flavor determination (Efriwati et al. 2013). Samson et al. (1987) reported that sixty-nine percent of the samples of commercial tempeh in Nederland contained yeast more than $10^{5} \mathrm{cfu} / \mathrm{g}$. Contribution of yeasts to the properties of tempeh is in developing flavor and substrate modification and in the safety of the product (Surono 2016). Pangastuti et al. (2019) reported that 17 operational taxonomic units (OTUs) of fungi in over-fermented tempeh were detected. Among them, 9 OTUs had significant abundance: six species were identified as Tryblidiopsis sichuanensis, Candida sp.2_1., Kluyveromyces marxianus, Trichosporon asahii, T. gracile, and T. ovoides.

Diversity of microflora species that can be collected from traditional fermented foods depends on the region, carbon source (substrate), water activity (aw) raw material and weather during the fermentation process (Astriani et al. 2018). Therefore, the research uses several types of traditional food with different raw materials, so that information on various types of yeast isolates with different phytase activities will be obtained.

\section{Qualitative screening of phytate-degrading yeast}

Qualitative screening is an important step to determine the ability of the isolates in the production of an enzyme. This procedure can be conducted by propagating microorganisms under selective pressures or by supplementing growth medium with suitable substrate. This method would induce the production of the enzyme itself. Based on experiments that have been carried out, it was known that eight yeast isolates can produce phytase enzymes. It was observed from the formation of clear zones around the yeast colony after the cobalt chloride staining process (Table 2).

The statistical analysis of the clear zone diameter resulted that there were significant differences within the eight isolates. The highest clear zone diameter was found in GF-1 followed by TKd-5 and TKd-3 isolates. The qualitative assay of phytase production carried out by Ranjan and Sahay (2013) resulted that 5 yeast isolates produced different clear zone diameters including $C$. parapsilosis CB3 (40 mm), Candida spp. SP3 (22 mm), Debaromyces spp. (30 mm), Dipodascus spp. CF2 (24 mm) and Dipodascus spp. PTC $(33 \mathrm{~mm})$. The formation of a clear zone around the yeast colony occurs due to the hydrolysis of sodium phytate as a source of phosphate by phytase produced by yeast (Fossi et al. 2016).

\section{Phytase activity assay}

Eight isolates that were obtained from the previous screening were subjected to the phytase activity assay based on Vohra and Satyanarayana (2001) method. The result of this assay showed in Table 3 . The specific phytase activity was obtained by determination of soluble proteins in each yeast isolate. The results of this study indicate that the highest phytase activity produced by TKd-3 isolates followed by GF-1 isolates. The highest soluble protein levels were found in isolates TKd-6. Measurement of dissolved protein levels in microbes has been carried out by Sasirekha et al (2012) who measured dissolved protein levels produced by Pseudomonas aeruginosa p6 with dissolved protein levels in crude extracts of $0.072 \mathrm{mg} / \mathrm{mL}$. Another study conducted by Thyagarajan et al (2014) revealed that dissolved protein level in crude extracts phytase produced by Hypocrea ixii Surt01 was $0.302 \mathrm{mg} / \mathrm{mL}$.

The specific activity of phytase enzymes is the ability of phytase enzymes to degrade substrate per mg of protein that is suspended in solution (Blanch and Clark 1996). According to Bedford and Patridge (2010), the magnitude of the specific activity of phytase enzymes plays an important role in determining the ability of phytase enzymes to degrade substrates. This is related to determining the dose of enzyme administration during the process of applying the enzyme.

Table 1. Total yeast isolate from traditional fermented food

\begin{tabular}{lcc}
\hline Source of isolate & $\begin{array}{c}\text { Code of } \\
\text { isolates }\end{array}$ & $\begin{array}{c}\text { Number of culturable } \\
\text { yeast isolate }\end{array}$ \\
\hline Soybean tempe & TKd & 8 \\
Gebus tempe & TGb & 3 \\
Manding tempe & TMd & 1 \\
Koro tempe & TKr & 2 \\
Fresh gatot & GF & 2 \\
Cooked gatot & GC & 1 \\
Total isolates & & 17 \\
\hline
\end{tabular}

Table 2. Clear zone diameter of the selected yeast isolated from traditional fermented food

\begin{tabular}{cc}
\hline Code of isolates & Clear zone diameter $(\mathbf{c m})$ \\
\hline TKd-2 & $0.530 \pm 0.069^{\mathrm{d}}$ \\
TKd-3 & $0.738 \pm 0.023^{\mathrm{bc}}$ \\
TKd-5 & $0.813 \pm 0.071^{\mathrm{b}}$ \\
TKd-6 & $0.575 \pm 0.130^{\mathrm{d}}$ \\
TKd-7 & $0.577 \pm 0.113^{\mathrm{d}}$ \\
TGb-23 & $0.637 \pm 0.068^{\mathrm{cd}}$ \\
TKr-2 & $0.215 \pm 0.070^{\mathrm{e}}$ \\
GF-1 & $0.965 \pm 0.082^{\mathrm{a}}$ \\
P-value & $0.00^{* * *}$ \\
\hline
\end{tabular}

Note: Value in the same column with different superscript shown significantly different $(\mathrm{P}<0.05)$

Table 3. Phytase activity of selected yeast isolates

\begin{tabular}{lccc}
\hline $\begin{array}{c}\text { Isolate } \\
\text { code }\end{array}$ & $\begin{array}{c}\text { Phytase } \\
\text { activity } \\
\text { (U/mL) }\end{array}$ & $\begin{array}{c}\text { Soluble } \\
\text { protein } \\
(\mathbf{m g} / \mathbf{m L})\end{array}$ & $\begin{array}{c}\text { Specific } \\
\text { phytase } \\
\text { activity }\end{array}$ \\
\hline TKd-2 & $2.017 \pm 0.917^{\mathrm{d}}$ & $0.085 \pm 0.000^{\mathrm{c}}$ & $29.066 \pm 5.380^{\mathrm{c}}$ \\
TKd-3 & $6.572 \pm 0.096^{\mathrm{a}}$ & $0.120 \pm 0.002^{\mathrm{b}}$ & $54.506 \pm 0.191^{\mathrm{a}}$ \\
TKd-5 & $3.767 \pm 0.333^{\mathrm{c}}$ & $0.102 \pm 0.025^{\mathrm{bc}}$ & $38.043 \pm 6.485^{\mathrm{b}}$ \\
TKd-6 & $1.100 \pm 0.083^{\mathrm{e}}$ & $0.181 \pm 0.006^{\mathrm{a}}$ & $6.065+0.364^{\mathrm{d}}$ \\
TKd-7 & $5.392 \pm 0.292^{\mathrm{b}}$ & $0.104 \pm 0.008^{\mathrm{bc}}$ & $51.887 \pm 3.263^{\mathrm{a}}$ \\
TKr-2 & $3.544 \pm 0.509^{\mathrm{c}}$ & $0.109 \pm 0.024^{\mathrm{bc}}$ & $33.172 \pm 5.620^{\mathrm{bc}}$ \\
TGb-23 & $0.767 \pm 0.000^{\mathrm{e}}$ & $0.102 \pm 0.006^{\mathrm{bc}}$ & $7.514 \pm 0.419^{\mathrm{d}}$ \\
GF-1 & $6.072 \pm 0.694^{\mathrm{ab}}$ & $0.115 \pm 0.036^{\mathrm{bc}}$ & $53.682 \pm 5.970^{\mathrm{a}}$ \\
\hline
\end{tabular}

Note: Value in the same column with different superscript shown significantly different $(\mathrm{P}<0.05)$ 


\section{Morphology identification of selected yeast isolate}

The samples' achievement of high-quality SEM images must have good conductivity, thermal stability, and a high secondary electrical yield (Liu 2000). Organic samples have low conductivity; it can be improved by making sample preparations first before observed using SEM. Karimy et al. (2020) had used a simple and quick method of specimen preparation to observe the morphology of Saccharomyces cerevisiae B-18 without using any chemical fixative. Because of that, in this research, we use that method to prepare the yeast samples. We can use this method to screen and know the budding cells of $C$. tropicalis TKd-3 and GF-1 using SEM with high-pressure vacuum mode without disturbing their cell morphology.

The results of morphological identification using Scanning Electron Microscopy (SEM) showed that the yeast isolate from soybean tempeh (TKd-3) had an elongated oval cell structure, while the yeast isolate from fresh gatot (GF-1) had a rounder cell structure (Figure 1). SEM is a method of identification and characterization with higher resolution results than a light microscope so that it can observe object structures more clearly and in detailed (Sujatno et al. 2015).

The type of yeast cell diameter has around five to ten micrometers. Yeast cells reproduce through a process called budding. Budding has resulted from asymmetric asexual cell division called the bud. The bud has resulted if once a "mother" cell reaches a maximum size, and it gives rise to a "daughter" cell (Nguyen et al. 2017). Based on analysis using ImageJ software resulted that the average length of TKd3- cell was $5.685 \pm 0.343$ whereas GF-1 cell was $4.408 \pm 0.388 \mu \mathrm{m}$. According to Larone (2002), yeast cells' growth in the log phase as budding cells (blastoconidia), under optimal nutrition and standard condition, the dimension of spherical to oval in shape is approximately 2-5 x 3-7 $\mu \mathrm{m}$. Morphology characteristics of C. tropicalis are had no germ tube production; it has or has not hyphae, has pseudohyphae, yeast size 4-8 x 5-11 ( $\mu \mathrm{m})$ (Silva et al. 2012).

\section{Biochemical identification}

Biochemical identification was performed in 2 selected yeast that had the highest specific phytase activity. Biochemical assays for yeast identification were carried out using the API 20C AUX V5.0 Kit (Biomerieux 2010). The ability of selected yeast to assimilate different sugars was presented in Table 4.

The results of the biochemical identification of this Kit are determined based on the turbidity or non-turbidity of the sugar substrate by equating the turbidity with 2 McFarland (Corin and Tri 2014). Sugar substrate that becomes turbid indicates that the isolate reacts positively, whereas sugar substrate which does not become turbid indicates negative reaction. The results of the 20C AUX V5.0 API Kit test can be known after being incubated for 72 hours, then identified using the apiwebTM software to identify possible isolates (Biomerieux 2010).

Table 4. Identification of yeast using API 20 20C AUX V5.0 kit

\begin{tabular}{llcc}
\hline \multicolumn{1}{c}{ Code } & \multicolumn{1}{c}{ Sugar } & TKd-3 & GF-1 \\
\hline 2KG & Calcium 2-keto-gluconate & + & - \\
ADO & Adonitol & + & - \\
ARA & L-arabinose & - & - \\
CEL & D-cellobiose & + & - \\
GAL & D-galactose & + & - \\
GLU & D glucose & + & + \\
GLY & Glycerol & + & + \\
INO & Inositol & - & - \\
LAC & D-lactose/ bovine origin & + & - \\
MAL & D-maltose & + & + \\
MDG & Methyl- $\alpha$ D-glucopyranoside & + & + \\
MLZ & D-melezitose & + & + \\
NAG & N-xylose Acetyl-Glucosamine & + & - \\
O & Control & - & - \\
RAF & D-raffinose & - & + \\
SAC & D-saccharose/ sucrose & + & + \\
SOR & D-sorbitol & + & + \\
TRE & D-trehalose & + & + \\
XLT & Xylitol & + & - \\
XYL & D-xylose & + & - \\
H/PH+ & & - & - \\
\hline NOte: $(-):$ & Ot ableto assimilate, & + ) & +
\end{tabular}

Note: (-): not able to assimilate, (+): able to assimilate

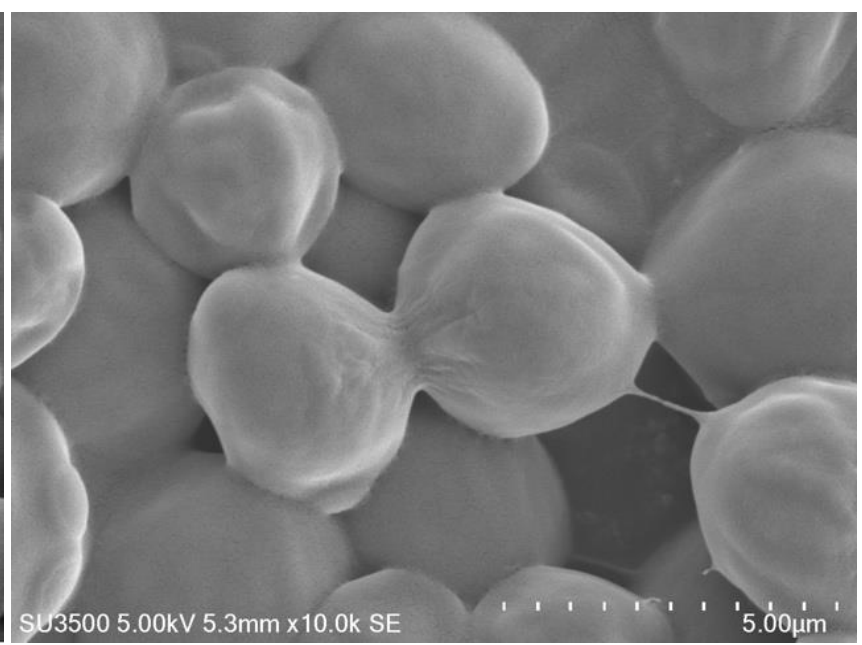

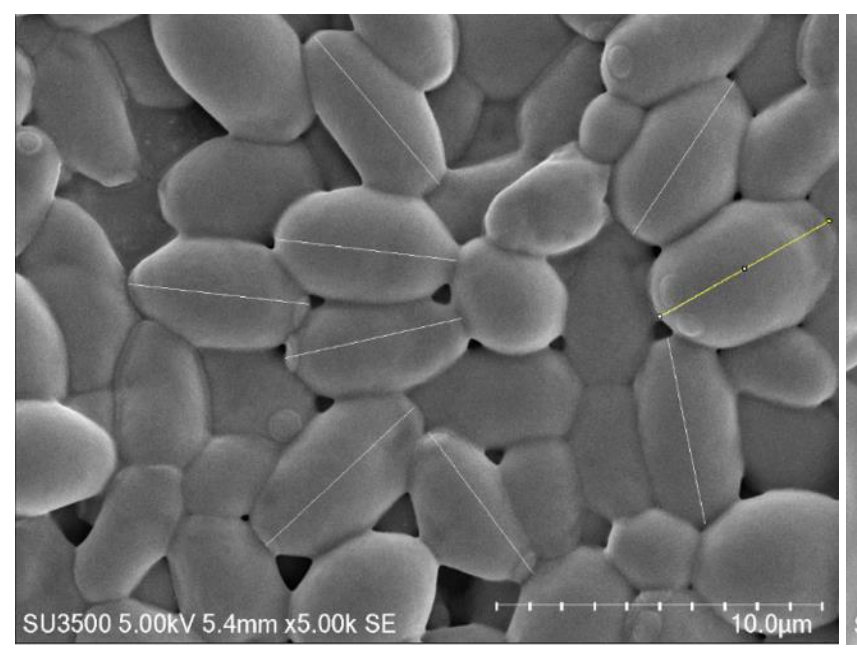

Figure 1. Observation of TKd3 cell (left) and GF1 cell (right) with magnification 10.000x and vacc $10 \mathrm{kV}$ 
Based on the results of biochemical identification of TKd-3 isolates using API 20C AUX and apiweb ${ }^{\mathrm{TM}}$ software showed that TKd-3 isolates homologous with Candida famata with a similarity level of $99.7 \%$. The results of biochemical identification of GF1 isolates show that GF-1 isolates homologous with Candida pelliculosa with a similarity level of $93.8 \%$. The identification result of biochemical assay might be different from other identification methods, therefore molecular identification using gene sequence data are needed. According to Rinanda (2011), molecular identification results are more accurate identification and faster processing. Zhao et al. (2017) stated that identification of gene sequences originating from yeast isolates is a gold standard identification method, while the biochemical identification method using API 20C AUX only has an accuracy rate of $78.9 \%$.

\section{Molecular identification of selected yeast isolate}

Characterization of yeast isolates was carried out based on DNA 28S rRNA coding to determine the genus and strains. PCR-28S rRNA sequences after assembly then BLAST on November 28, 2018. Molecular identification was performed in Table 5. The sequences obtained by the contig assembly were analyzed using the nucleotide Basic Local Alignment Search Tool (BLAST) method (https://blast.ncbi.nlm.nih.gov/Blast.cgi) to obtain regions that are close to microbial sequences on the bioinformatics database and get statistical significance. The results of analysis with BLAST are used as a reference for determining the type of sequenced species with a certain percentage of proximity. Analysis of the relationship between species and reference species (type strain) was obtained from nucleotide data in the NCBI database by making phylogenetic trees. FASTA nucleotide sequence data of analyzed species and reference species were collected in one notepad file. Sequence data is loaded in the ClustalX2.1 program (Thompson et al. 1997). Sequence data was analyzed for alignment and continued with bootstrap N-J tree. Phylogeny tree construction was carried out using Neighbor-Joining Tree analysis with bootstrap 1000 replications using MegaX version 10.0.5 software (Kumar et al. 2018) (Figure 2)

Table 5 showed TKd3 isolate with accession number MW131530 had submitted on GenBank (https://www.ncbi.nlm.nih.gov/nuccore/MW131530),

October 24, 2020, had homology with Candida tropicalis ATCC 750 28S rRNA accession number NG 054834.1 with $99.83 \%$ similarity and GF1 isolate with accession number MW131531 had submitted on GenBank (https://www.ncbi.nlm.nih.gov/nuccore/MW131531),

October 24, 2020, had homology with Candida tropicalis ATCC 750 28S rRNA accession number NG 054834.1 with $100 \%$ similarity.

The identification results through biochemical identification using API 20C AUX had a similarity range of 93.8 and $99.7 \%$, while the molecular test results reached 99.83 and $100 \%$ similarity, this shows that molecular identification is a more accurate identification method for determining the genus and strain of isolates compared to biochemical test methods. Liguori et al. (2009) stated that biochemical tests using API 20C AUX to get the right results required precision inoculation techniques, skilled interpretation staff, and the time to read the exact results of inoculation. Fenn et al. (1994) in their research results stated that the isolation of yeast tested with API 20C AUX obtained 99\% exact results, while Davey et al. (1995) stated that identification using API 20C AUX only obtained $88 \%$ of the accurate identification results.

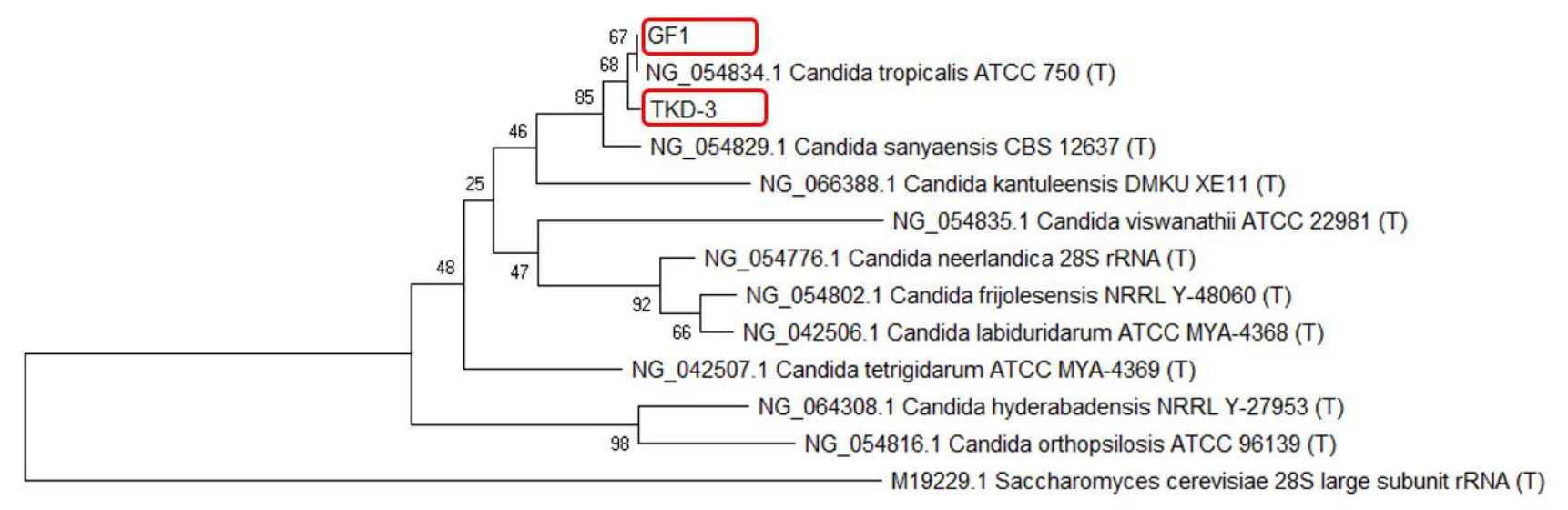

0.010

Figure 2. Phylogenetic position of isolates TKd-3 and GF-1

Table 5. Molecular identification of selected yeast

\begin{tabular}{lll}
\hline \multicolumn{1}{c}{ Isolate } & \multicolumn{1}{c}{ Identification } \\
\cline { 2 - 3 } & \multicolumn{1}{c}{ Biochemical (API 20C AUX) } & \multicolumn{1}{c}{ Molecular (28S rRNA) } \\
\hline TKd-3 MW131530 & Candida famata $(99.7 \%)$ & Candida tropicalis ATCC 750 28S rRNA (99.83\%) \\
GF-1 MW131531 & Candida pelliculosa $(93.8 \%)$ & Candida tropicalis ATCC 750 28S rRNA (100\%) \\
\hline
\end{tabular}


Molecular identification is known to provide a more objective separation of genera and species than phenotypic analysis. Candida is one of amylolytic yeast that was founded in various types of fermented products. $C$. tropicalis BOM 21 isolated from some cereal-based Nigerian traditional fermented food products with multifunctional potential that can be exploited as starter culture to produce cereal-based functional products (Ogunremi et al. 2015). Twenty yeast strains were isolated from traditional Indian fermented foods (idli and jalebi batter) for various probiotic properties, and identified as Aureobasidium sp., Candida tropicalis, Pichia manshurica, and Saccharomyces cerevisiae (Syal and Vohra 2013). Ebabhi et al (2013) found C. tropicalis, K. marxianus, $P$. caribbica and $S$. cerevisiae isolated from Manihot esculenta, Zea mays, Cola acuminata and Sorghum bicolor, that have the potential to ferment both hexose and pentose sugars. Maïworé et al. (2019) reported that $C$. tropicalis were present in traditional yogurts and traditionally fermented milk in northern Cameroon. Anti-listerial hydrophobic peptides secreted by Debaryomyces hansenii, Pichia fermentans, C. tropicalis and Wickerhamomyces anomalus, isolated from cheese which found by Hatoum et al (2013). Isolate YCG7 isolated from fermented condiment and food identified as $C$. tropicalis with responsible for the fermentation of food through their enzymatic activity, improved food safety, the enrichment of nutrients, and the promotion of health of consumers (Cissé et al. 2019). From the 43 indigenous sub-Saharan African fermented food and beverages investigated, a total of 98 different yeast species have been identified. $S$. cerevisiae was reported in $77 \%$ of the fermented products, being the predominant yeast species isolated, followed by Pichia kudriavzevii reported in $60 \%$, Candida tropicalis in $47 \%$ and Kluyveromyces marxianus (anamorph Candida kefyr) in $44 \%$ of the fermented products. C. tropicalis is most frequently $(71 \%)$ isolated and identified from indigenous sub-Saharan African solid fermented foods (Johansen et al. 2019).

\section{ACKNOWLEDGEMENTS}

The authors gratefully thank the DIPA Indonesian Institute of Sciences (LIPI) for financial support and thanks to Madina Nurohmah for supporting this research.

\section{REFERENCES}

Abd El-Hack ME, Alagawany M, Arif M, Emam M, Saeed M, Arain MA Siyal FA, Patra A, Elnesr SA, Khan RU. 2018. The uses of microbial phytase as a feed additive in poultry nutrition - a review. Ann Anim Sci 18 (3): 639-658.

Aidoo KE, Nout MJR, Sarkar PK. 2005. Occurrence and function of yeast in Asian indigenous fermented foods. FEMS Yeast Res 6: 30-39. DOI: $10.1111 / \mathrm{j} .1567-1364.2005 .00015 . x$.

Astriani A, Diniyah N, Jayus J, Nurhayati N. 2018. Phenotypic identification of indigenous fungi and lactic acid bacteria isolated from 'gatot' an Indonesian fermented food. Biodiversitas 19: 947954. DOI: 10.13057/biodiv/d190325
Bae HD, Yanke L, Cheng KJ, Seliner RB. 1999. A novel staining method for detecting Phytase activity. J Microbiol Method 39: 17-22. DOI: 10.1016/S0167-7012(99)00096-2.

Basu S, Tomar KS, Hati S. 2015. Isolation and identification of Phytatedegrading Lactobacilli from Indian cereal-based fermented milk product "Raabadi". Int J Fermented Food 4 (1): 49-59.

Bedford M, Partridge G. 2010. Enzyme in Farm Animal Nutrition. $2^{\text {nd }}$ ed. CAB International, London.

Blanch WH, Clark SD. 1996. Biochemical Engineering $2^{\text {nd }}$ Edition. Marcel Dekker Inc, New York.

Biomerieux. 2010. BioMérieux, Inc., Durham.

Bonner RLP. 2007. Protein Purification. Taylor and Francis Group, New York.

Cissé H, Kagambèga B, Sawadogo A, Tankoano A, Sangaré G, Traoré Y, Ouoba IIL, Savadogo A. 2019. Molecular characterization of Bacillus, lactic acid bacteria and yeast as potential probiotics isolated from fermented food. Sci Afr 6: e00175. DOI: 10.1016/j.sciaf.2019.e00175.

Cohort. 2008. CoSTAT Version 6.400. Cohort Software 798. Lighthouse Ave, Monterey, USA.

Corin C, Tri A. 2014. Produksi protein sel tunggal isolat khamir asal limbah pabrik kecap dengan metode co-culture. Jurnal Biotropika 2 (3): 181-185. [Indonesian]

Damayanti E, Ratisiwi FN, Istiqomah L, Sembiring L, Febrisiantosa A 2017. Phytate degrading activities of lactic acid bacteria isolated from traditional fermented food. AIP Conf Proc 1823: 020053. DOI: 10.1063/1.4978126.

Davey KG, Chant PM, Downer CS, Campbell CK, Warnock DW. 1995. Evaluation of the AUXACOLOR system, a new method of clinical yeast identification. J Clin Pathol 48 (9): 807-809. DOI: 10.1136/jcp.48.9.807.

Dersjant-Li Y, Awati A, Schulze H, Patridge G. 2014. Phytase in nonruminant animal nutrition: A critical review on phytase activities in the gastrointestinal tract and influencing factors. Sci Food Agric 95: 878-896. DOI: 10.1002/jsfa.6998.

Ebabhi AM, Adekunle AA, Okunowo W, Oluwanisola AM, Osuntoki AA. 2013. Isolation and characterization of yeast strains from local food crops. J Yeast Fungal Res 4 (4): 38-43.

Efriwati, Suwanto A, Rahayu G, Nuraida L. 2013. Population dynamics of yeast and lactic acid (LAB) during tempeh production. Hayati J Biosci 20 (2): 57-64. DOI: 10.4308/hjb.20.2.57.

Fenn JP, Segal H, Barland B, Denton D, Whisenant J, Chun H, Christofferson K, Hamilton L, Carroll K. 1994. Comparison of updated Vitek yeast biochemical card and API 20C yeast identification systems. J Clin Microbiol 32 (5): 1184-1187.

Fossi TB, Akwanwi MC, Takop GN, Bille YE, Wanji S. 2016. Phytic acid degradation by selected Lactobacilli isolated from fruits and vegetables and their potential as probiotics. Eur J Biotechnol Biosci 4 (7): 34-41.

Gomez KA, Gomez AA. 2007. Statistical Procedures for Agricultural Research. $2^{\text {nd }}$ ed. UI Press, Jakarta.

Greppi A, Krych Ł, Costantini A, Rantsiou K, Hounhouigan DJ, Arneborg N, Cocolin L, Jespersen L. 2015. Phytase-producing capacity of yeasts isolated from traditional African fermented food products and PHYPk gene expression of Pichia kudriavzevii strains. Int J Food Microbiol 205: 81-89. DOI: 10.1016/j.ijfoodmicro.2015.04.011.

Hall TA. 1999. BioEdit: a user-friendly biological sequence alignment editor and analysis program for Windows 95/98/NT. Nucleic Acids Symp Ser 41: 95-98.

Hatoum R, Labrie S, Fliss I. 2013. Identification and partial characterization of antilisterial compounds produced by dairy yeasts. Probiotics Antimicrob Proteins 5: 8-17. DOI: 10.1007/s12602-0129109-8.

Hellstorm MA, Juarez VR, Svanberg U, Andlid TA. 2010. Biodiversity and Phytase capacity of yeasts isolated from Tanzania togwa. Intl J $\begin{array}{lllll}\text { Food Microbiol } 136 & \text { (1): } & 352-358 . & \end{array}$ 10.1016/j.ijfoodmicro.2009.10.011.

Johansen PG, Owusu-Kwarteng J, Parkouda C, Padonou SW, Jespersen L. 2019. Occurrence and importance of yeasts in indigenous fermented food and beverages produced in Sub-Saharan Africa. Front Microbiol 10: 1789. DOI: 10.3389/fmicb.2019.01789.

Kabak B, Dobson ADW. 2011. An introduction to the traditional fermented foods and beverages of Turkey. Crit Rev Food Sci Nutr 51 (3): 248-260. DOI: 10.1080/10408390903569640. 
Kanti A, Sudiana IM. 2016. Comparison of Neurospora crassa and Neurospora sitophila for Phytase production at various fermentation temperatures. Biodiversitas 17: 769-775. DOI: $10.13057 /$ biodiv/d170253.

Kanti A, Sudiana MI. 2018. Production of Phytase, Amylase and Cellulase by Aspergillus, Rhizopus and Neurospora on mixed rice straw powder and soybean curd residue. Earth Environ Sci 166 (1): 110 .

Karimy MF, Damayanti E, Suryani AE, Prasetyo E, Nurhayati R, Anwar M, Anggraeni AS. 2020. A simple method for analysis of Saccharomyces cerevisiae morphology by applying a high vacuum mode of the scanning electron microscopy and without chemical fixatives. E \& ES 462 (1): 012048.

Kumar S, Stecher G, Li M, Knyaz C, Tamura K. MEGA X: Molecular evolutionary genetics analysis across computing platforms. Mol Biol Evol 35 (6): 1547-1549. DOI: 10.1093/molbev/msy096.

Lambrechts C, Boze H, Moulin G, Galzy P. 1992. Utilization of Phytate by some yeasts. Biotechnol Lett 14: 63-66. DOI: 10.1007/BF01030915

Larone D. 2002. Medically Important Fungi: A Guide to Identification $4^{\text {th }}$ Ed. ASM Press, Washington.

Liguori G, Di Onofrio V, Lucariello A, Gallè F, Signoriello G, Colella G, D'amora M, Rossano F. 2009. Oral candidiasis: A comparison between conventional methods and multiplex PCR for species identification. Oral Microbiol Immunol 24 (1): 76-78. DOI 10.1111/j.1399-302X.2008.00447.x.

Liu J. 2000. High-resolution and low-voltage FE-SEM imaging and microanalysis in materials characterization Mater. Charact 44: 353363.

Lowry OH, Rosebrough NJ, Farr AL, Randall RJ. 1951. Protein measurements with the folin phenol reagent. J Biochem 193: 265-275.

Maïworé J, Ngoune LT, Piro-Metayer I, Montet D. 2019. Identification of yeasts present in artisanal yogurt and traditionally fermented milk consumed in the northern part of Cameroon. Sci Afr 6: e00159. DOI: 10.1016/j.sciaf.2019.e00159.

Mittal A, Singh G, Goyal V, Yadav A, Aneja KR, Gautam S, Aggarwa NK, 2011. Isolation and biochemical characterization of acidothermophilic extracellular phytase producing bacterial strain for potential application in poultry feed. Jundishapur J Microbiol 4: 273 282.

Monica, Savitri, Kumar V, Kumari A, Angmo K, Bhalla TC. 2017. Isolation and characterization of lactic acid bacteria from traditional pickles of Himacal Pradesh, India. J Food Sci Technol 54 (7): 19451952. DOI: $10.1007 / \mathrm{s} 13197-017-2629-1$

Nguyen K, Murray S, Lewis JA, Kumar P. 2017. Morphology, cell division, and viability of Saccharomyces cerevisiae at high hydrostatic pressure. arXiv preprint arXiv:1703.00547. 1-19.

Noubariene L, Arneborg N, Hansen AS. 2014. Phytase Active Yeast Isolated from Bakery Sourdoughs. $9^{\text {th }}$ Baltic Conference of Food Science and Technology.

Ogunremi OR, Sanni AI, Agrawal R. 2015. Probiotics potentials of yeasts isolated from some cereal-based Nigerian traditional fermented products. J Appl Microbiol 119 (1): 797-808. DOI: 10.1111/jam.12875.

Olstrope M, Schnurer J, Passoth V. 2009. Screening of yeast strain for Phytase activity. FEMS Yeast Res 9 (3): 478-488. DOI 10.1111/j.1567-1364.2009.00493.x.

Pandey A, Szakacs G, Soccol CR, Rodriguez-Leon JA, Soccol VT. 2001. Production, purification and properties of microbial phytases. Bioresour Technol 77: 203-214. DOI: 10.1016/S0960 8524(00)00139-5.

Pangastuti A, Alfisah RK, Istiana NI, Sari SLA, Setyaningsih R, Susilowati A, Purwoko T. 2019. Metagenomic analysis of microbial community in over-fermented tempeh. Biodiversitas 20 (4) : 1106 1114. DOI: $10.13057 /$ biodiv/d200423.

Puppala RK, Naik T, Shaik A, Dastager S, Kumar VR, Khire J, Dharne M. 2018. Evaluation of Candida tropicalis (NCIM 3321) extracellular Phytase having plant growth promoting potential and process development. Biocatalys Agric Biotechnol 13 (1): 225-235. DOI: 10.1016/j.bcab.2017.12.013.

Qasim SS, Shakir KA, Al-Shaibani AB. 2016. Purification of Phytase produced from a local fungal isolate and its application in food system. Iraqi J Agric Sci 47 (1): 112-120.

Ranjan K, Sahay S. 2013. Identification of Phytase producing yeasts, optimization and characterization of extracellular Phytase from Candida parapsilosis. Int J Sci Nat 4 (4): 583-590.

Rinanda T. 2011. Analisis sekuensing 16rRNA di bidang mikrobiologi. Jurnal Kedokteran Syiah Kuala 11 (3): 172-177.

Rodehutscord M, R“uckert C, Maurer HP, Schenkel H, Schipprack W, Bach Knudsen KE, Schollenberger M, Laux M, Eklund M, Siegert W. 2016. Variation in chemical composition and physical characteristics of cereal grains from different genotypes. Arch Anim Nutr 70: 87107. DOI: 10.1080/1745039X.2015.1133111.

Samson RA, Van Kooij JA, De Boer E. 1987. Microbiological quality of commercial tempeh in the Netherlands. J Food Prot 50: 92-94. DOI: 10.4315/0362-028X-50.2.92.

Sarwono B. 2010. Usaha Membuat Tempe dan Oncom. PT Niaga Swadaya, Surabaya. [Indonesian]

Sasirekha B, Bedashree T, Champa KL. 2012. Optimization and partial purification of extracellular Phytase from Pseudomonas aeruginosa p6. Eur J Exp Biol 2 (1): 95-104

Savita PD, Suvarna VC, Annu T, Balakrishna AN, Kanchanashri B, Yallapa M. 2017. Characterization and identification of Phytate solubilizing yeasts isolated from food grains. Int J Curr Microbiol App Sci 4: 1184-1192.

Schneider CA, Rasband WS, Eliceiri KW. 2012. NIH Image to ImageJ: 25 years of image analysis. Nat Methods 9 (7): 671-675. DOI: 10.1038/nmeth.2089

Shanmugam G. 2018. Characteristics of Phytase enzyme and its role in animal nutrition. Int J Curr Microbiol App Sci 7 (3): 1006-1013.

Silva S, Negri M, Henriques M, Oliveira R, Williams DW, and Azeredo J. 2012. Candida glabrata, Candida parapsilosis and Candida tropicalis: biology, epidemiology, pathogenicity and antifungal resistance. FEMS Microbiol Rev 36 (2): 288-305. DOI: 10.1111/j.1574-6976.2011.00278.x

Steiner T, Mosenthin R, Zimmermann B, Greiner R, Roth S. 2007. Distribution of Phytase activity, total phosphorus and phytate phosphorus in legume seeds, cereals and cereal by-products as influenced by harvest year and cultivar. Anim Feed Sci Technol 133: 320-334. DOI: 10.1016/j.anifeedsci.2006.04.007

Sujatno A, Salam R, Bandriyana B, Dimyati A. 2015. Studi scanning electron microscopy (SEM) untuk karakterisasi proses oxidasi paduan zirkonium. Jurnal Forum Nuklir (JFN) 9: (1): 44-50. [Indonesian]

Surono IS. 2016. Ethnic fermented foods and beverages of Indonesia. In Ethnic fermented foods and alcoholic beverages of Asia. Springer, New Delhi.

Syal P, Vohra A. 2013. Probiotic potential of yeasts isolated from traditional Indian fermented foods. Intl J Microbiol 5 (2): 390-398.

Thompson JD. Gibson TJ, Plewniak F, Jeanmougin F, Higgins DG. 1997. The CLUSTAL_X windows interface: flexible strategies for multiple sequence alignment aided by quality analysis tools. Nucleic Acids Res 25 (24): 4876-4882. DOI: 10.1093/nar/25.24.4876

Thyagarajan R, Namasivayam SKR, Narendrakumar G. 2014. Partial purification of Phytase from Hypocrea lixii SURT01, a poultry isolate. Int J Pharm Bio Sci 5 (4): 680-687.

Torshizi MK, Rahimi S, Mojgani N, Esmaeilkhanian S, Grimes JL. 2008. Screening of indigenous strains of lactic acid bacteria for development of a probiotic for poultry. Asian-Aust J Anim Sci 21 (10): 1495-1500.

Vohra A, Satyanarayana T. 2001. Phytase production by the yeast, Pichia anomala. Biotechnol Lett 23 (7): 551-554. DOI: 10.1023/A:1010314114053

Zhao Y, Tsang C, Xiao M, Chan JFW, Lau SKP, Kong F, Xu Y, Woo PCY. 2018. Yeast identification by sequencing, biochemical kits, MALDI-TOF MS and rep-PCR DNA fingerprinting. Med Micol 56: 816-827. DOI: 10.1093/mmy/myx118. 